\title{
Effects of bacterial inoculants and an enzyme on the fermentation quality and aerobic stability of ensiled whole-crop sweet sorghum
}

\author{
B.D. Nkosi ${ }^{1,2 \#}$, P.V. Vadlani ${ }^{2}$, K. Brijwani ${ }^{2}$, A. Nanjunda ${ }^{2}$ \& R. Meeske $^{3}$ \\ ${ }^{1}$ Division of Animal Nutrition: ARC- Animal Production Institute, Private Bag x 2, Irene, 0062, South Africa \\ ${ }^{2}$ Bioprocessing and Industrial Value Added Program (BIVAP), Grain Science and Industry, Kansas State University, \\ Manhattan, KS 66506, USA \\ ${ }^{3}$ Outeniqua Research Farm, P.O. Box 249, George, 6530, South Africa \\ Copyright resides with the authors in terms of the Creative Commons Attribution 2.5 South African Licence. \\ See: http://creativecommons.org/licenses/by/2.5/za \\ Condition of use: The user may copy, distribute, transmit and adapt the work, but must recognise the authors and the South African Journal of \\ Animal Science.
}

\begin{abstract}
A study was conducted to evaluate the effects of bacterial inoculation and cellulase on the fermentation quality of ensiled whole-crop sweet sorghum (WCSS, Sorghum bicolor L. Moench). The WCSS (323 g dry matter (DM)/kg, $251 \mathrm{~g}$ water soluble carbohydrates (WSC) $/ \mathrm{kg} \mathrm{DM}, 43 \mathrm{~g}$ crude protein (CP)/kg DM and $439 \mathrm{~g}$ neutral detergent fibre (NDF)/kg DM) was ensiled with i) no additive (control); ii) Lactobacillus buchneri (LB); iii) Lactobacillus plantarum (LP); and iv) LB+E, a combination of LB and enzyme. These treatments were ensiled in $1 \mathrm{~L}$ anaerobic jars for 25 days. The jars were opened on days 3, 7 and 15 to determine $\mathrm{pH}$, while those of day 25 were sampled to determine nutrient composition, fermentation characteristics and aerobic stability. Inoculation reduced $\mathrm{pH}$, butyric acid and ammonia- $\mathrm{N}$ and increased lactic acid content in sweet sorghum silage compared with the control. The aerobic stability of WCSS was improved with LB, while it was reduced with the homofermentative LP treatment compared with the control. The $\mathrm{LB}+\mathrm{E}$ reduced the fibre, but increased residual WSC of silage. The aerobic stability of $\mathrm{LB}+\mathrm{E}$ silage was lower than LB treated silage. Using enzymes to increase the WSC content of crops that already have high levels of WSC may result in reduced aerobic stability of silage. Further work is needed to evaluate these effects on silage produced on farm scale and on animal production performance.
\end{abstract}

Keywords: Aerobic stability, enzyme, fermentation, inoculants, silage

\# Corresponding author: Dnkosi@arc.agric.za

\section{Introduction}

Sweet sorghum (Sorghum bicolor L. Moench) has sweet juicy stems and has been used predominantly to produce ethanol through solid-state fermentation (Bryan, 1990; Putman et al., 1991). Owing to the high potential for preserving sugar in the stalks of sweet sorghum, this forage can be an ideal energy source for ruminants and good-quality silage can be produced (Adewakun et al., 1989, Felix \& Funso, 1994, Morris \& McCormick, 1994). However, whole-crop sweet sorghum (WCSS) is rich in lignocellulosic fibres (Billa et al., 1997), which may negatively affect nutrient digestibility (Aydin et al., 1999). Consequently, silage additives (bacterial inoculants, enzymes, etc.) have been used to improve the ensiling process and nutrient utilization by ruminants (Muck, 2010).

Although bacterial inoculants improved silage fermentation quality, their effects on fibre degradation is not consistent because lactic acid bacteria (LAB) cannot effectively use fibre as an energy source to produce lactic acid. Consequently, the addition of enzymes to forage at ensiling has been reported to degrade silage cell wall and increase the availability of WSC that serve as substrate for LAB (McDonald et al., 1991; Spoelstra et al., 1992; Selmer-Olsen et al., 1993; Sheperd \& Kung, 1996). Therefore, when LAB is combined with enzymes during ensiling, a stronger effect should be expected because more fermentable sugars will be released to produce more lactic acid in comparison with other fermentation products (Kung et al., 1991, Chen et al., 1994). In contrast, Stokes (1992) reported reduced enzyme activity in the presence of a $\mathrm{LAB}$ inoculant. 
Well-preserved and high-quality silages, particularly those inoculated with homofermentative LAB, can be more prone to spoilage than untreated silages (Muck, 2010). This can be attributed to the low production of acetic acid, which is well known to have an antifungal effect on aerobic micro-organisms (Weinberg et al., 1993). As a result, the problem of aerobic instability with homofermentative LAB inoculation can be solved with the use of Lactobacillus buchneri (LB), which has been reported to improve aerobic stability of silage in many studies (Taylor et al., 2002; Pedroso et al., 2008; Nkosi et al., 2009). In contrast, the heterofermentative pathway of LB can cause an increase in silage $\mathrm{pH}$, and losses in energy and dry matter (DM) content (Oude Elferink et al., 2001). However, if aerobic stability is improved, the loss of nutrients incurred by the addition of LB may be moderate in comparison with what might have been lost at feed out through aerobic deterioration.

Although the fermentable substrate is usually not a limiting factor for the fermentation of sweet sorghum during ensiling, an increase in ethanol content caused by enzyme treatment has led to poor aerobic stability of silage (Spoelstra et al., 1992). Xing et al. (209) reported poor aerobic stability of sweet sorghum silage treated with a homofermentative LAB and an enzyme mixture at ensiling. It was therefore hypothesized that an enzyme and LB mixture will improve the aerobic stability of sweet sorghum silage. The present study therefore aimed to evaluate the effects of bacterial and enzyme inoculation on the fermentation and aerobic stability of ensiled WCSS.

\section{Materials and Methods}

Whole crop sweet sorghum (hybrid M81E, KS Breeder, Mississippi State University, USA) was harvested in Manhattan, Kansas, USA at dough stage using a harvester adjusted to $15 \mathrm{~mm}$ cutting length. The inoculants, Lactobacillus buchneri (LB, strain ATCC 4005) and Lactobacillus plantarum (LP, strain ATCC 14917), were obtained from the American Type Culture Collection (ATCC, 10801 University Blvd, Manassas, VA, USA). The cellulose enzyme (Cellic ${ }^{\circledR}$ Ctec2) that contained 87 - 95 filter paper units (FPU)/mL activity with optimum $\mathrm{pH}$ of 5 (Lu et al., 2011), was obtained from Novozymes, Franklinton, N.C., USA. The inoculants (either LB or LP) were prepared by mixing $0.2 \mathrm{~g}$ inoculant with $32 \mathrm{~mL}$ of distilled water and sprayed over a $16 \mathrm{~kg}$ fresh WCSS to obtain at least $2.5 \times 10^{5}$ colony forming units of $\mathrm{LAB} / \mathrm{g}$ fresh WCSS. The enzyme was prepared by mixing $0.2 \mathrm{~g}$ Cellic ${ }^{\circledR} \mathrm{CTec} 2$ (enzyme complex consisting of cellulase, xylanase and beta-glucosidase activity) with $0.2 \mathrm{~g} \mathrm{LB}$, added to $32 \mathrm{~mL}$ distilled water and sprayed over $16 \mathrm{~kg}$ fresh WCSS. The application rates were done in accordance with the level of LAB and enzymes in the cultures as determined by the manufacturers. In order to add the same amount of moisture as in the treated WCSS, the control was treated with $32 \mathrm{~mL}$ of distilled water on $16 \mathrm{~kg}$ WCSS. The treatments were i) no inoculant (control), ii) LP, iii) LB and iv) LB+E, a combination of LB and cellulase enzyme. Triplicate samples $(n=3)$ from each treatment were collected and analysed for chemical composition before ensiling. The treatments were then ensiled in $48 \times 1 \mathrm{~L}$ jars (12 jars/treatment), kept at room temperature of 24 - $28{ }^{\circ} \mathrm{C}$. Each jar was filled with approximately $850 \mathrm{~g}$ (wet weight) chopped maize without headspace, and a packing density of $276( \pm 0.628) \mathrm{kg} \mathrm{DM} / \mathrm{m}^{3}$ was obtained. Three jars per treatment were opened on $\mathrm{d} 3,4,15$ and 25 of ensiling to determine $\mathrm{pH}$, while analysis for chemical composition and fermentation characteristics were done only on samples at day 25.

Aerobic stability of silage was defined as the number of hours that it took for the silage temperature to rise $2{ }^{\circ} \mathrm{C}$ above that of the ambient temperature. Samples of day 25 were subjected to a $5 \mathrm{~d}$ aerobic test, where $500 \mathrm{~g}$ of sample from each jar was loosely packed in an open plastic jar that was covered with two layers of cheesecloth and kept at $28{ }^{\circ} \mathrm{C}$. A temperature probe (ACR Smartbutton, ACR Systems Inc. Building 210-12960, 84 Avenue Surrey, BC, V3W 1K7, Canada) was placed in the geometric centre of the silage mass for each jar and also in the room where the jars were stored to record temperature. The room temperature and the temperature in each jar were monitored simultaneously at $1 \mathrm{~h}$ intervals for $5 \mathrm{~d}$.

A representative $40 \mathrm{~g}$ silage sample was taken from each jar to determine the fermentation characteristics. The $40 \mathrm{~g}$ silage sample $(\mathrm{n}=3)$ was mixed with $360 \mathrm{~mL}$ of distilled water in a stomacher bag, homogenized for $4 \mathrm{~min}$ and $\mathrm{pH}$ was determined immediately with a $\mathrm{pH}$ meter (Thermo Orion Model 525, Thermo Fisher Scientific, Waltham, MA, USA). It was then filtered through a Whatman No. 54 filter paper (Clifton, NJ, USA). The extract was used to determine $\mathrm{pH}$, water-soluble carbohydrates (WSC), volatile fatty acids (VFAs), lactic acid (LA) and ammonia-N. The WSC were determined by the Dubois et al.'s (1956) phenol-sulphuric acid method and LA was determined by the Pryce's (1969) modified colorimetric method The VFAs were determined with a Varian 3300 FID Detector gas chromatograph (Varian Associates, Inc., 
Palo Alto, CA, USA) by the procedure of Suzuki \& Lund (1980). Ammonia N was determined by distillation using a Buchi 342 apparatus and a Metrohm 655 Dosimat with an E526 titrator according to AOAC (ID 941.04, 1990).

The DM of the pre-ensiled mixtures and that of the silages were determined by drying the samples at $60{ }^{\circ} \mathrm{C}$ until a constant mass was achieved, and was corrected for loss of volatiles using Weissbach \& Strubelt's (2008) equation. After drying, the samples were ground through a 1-mm screen (Wiley mill, Standard Model 3, Arthur H. Thomas Co., Philadelphia, PA) for chemical analysis. The neutral detergent fibre (NDF) was analysed using Van Soest et al.'s (1991) method with a heat stable $\alpha$-amylase and sodium sulphate was added. The acid detergent fibre (ADF) was analysed using a Fibertec System 1010 (FOSS Analytical AB, Sweden) by boiling samples in an acidic solution followed by filtration (Van Soest et al., 1991). Separate samples were used for ADF and aNDF analysis and both included residual ash. Crude protein (CP) (ID 968.06) and ether extract (EE) (ID 963.15) were determined according to the procedure, while the gross energy (GE) was determined with an adiabatic bomb calorimeter (IKA C7000, Staufen, Germany).

Data were organized as a completely randomized design (CRD) with replicates nested within treatments. Therefore, a one-way analysis of variance (ANOVA) with Genstat (2005) was used to test for the differences among treatments using sample error as experimental error. Means of significant treatment effects $(P<0.05)$ were compared using the Student's t-LSD (least significant difference) at a 5\% significant level (Snedecor \& Cochran, 1980). The statistical model used was: $Y_{i j}=\mu+t_{i}+\beta_{j}+\varepsilon_{i j}$

where $Y_{i j}$ is the individual observations of the $i$-th treatment and the $j$-th replicate, $\mu$ is the overall mean, $t_{i}$ is the effect of the $\mathrm{i}$-th treatment, $\beta_{\mathrm{j}}$ is the effect of the $\mathrm{j}$-th replicate, and $\varepsilon_{i j}$ is the residual error.

\section{Results and Discussion}

The high sugar content in WCSS makes it an ideal forage for silage making. High residual sugar content in silage can serve as a dietary energy supplement for ruminants but may render the silage susceptible to aerobic deterioration during the feeding phase (Weinberg et al., 1993). Bacterial inoculants are added to forage at ensiling in order to stimulate lactic acid (LA) fermentation by accelerating the decrease in $\mathrm{pH}$, and thus improving silage preservation (McDonald et al., 2002). If low numbers of sufficient lactic acid bacteria (LAB) are present in the crop at ensiling, a slow rate of $\mathrm{pH}$ decrease will occur. Results for the chemical composition of pre-ensiled WCSS are shown in Table 1. When the silage DM content is lower than $300 \mathrm{~g} / \mathrm{kg}$ while having a high content of WSC, chances for ethanol production during fermentation are high (McDonald et al., 2002), which may reduce silage intake (Wilkins et al., 1971). The DM content of freshly chopped WCSS was $323 \mathrm{~g} \mathrm{DM} / \mathrm{kg}$, ideal for ensiling.

Table 1 Chemical composition ( $\mathrm{g} / \mathrm{kg}$ DM unless stated otherwise) of pre-ensiled whole-crop sweet sorghum $(\mathrm{n}=3)$

\begin{tabular}{lr}
\hline \multicolumn{1}{c}{ Parameter } \\
\hline Dry matter (DM), g/kg & $323 \pm 1.62$ \\
pH & $6.5 \pm 1.36$ \\
Water-soluble carbohydrate & $251 \pm 0.51$ \\
Ash & $42 \pm 0.27$ \\
Gross energy (MJ/kg DM) & $20.6 \pm 1.32$ \\
Crude protein & $43 \pm 0.35$ \\
Ether extract & $13 \pm 1.74$ \\
aNDF & $439 \pm 1.65$ \\
ADF & $282 \pm 0.92$
\end{tabular}

$\overline{\text { aNDF: amylase treated neutral detergent fibre; ADF: acid detergent fibre. }}$ 
A pH range of $3.7-4.2$ is generally considered beneficial for whole-crop cereal preservation (Kung \& Shaver, 2001) and that of our study was less than 3.9, indicative of well-preserved silage. Inoculation reduced $(P<0.05)$ the $\mathrm{pH}$ of sweet sorghum silage compared with the control, which is in agreement with previous studies (Fellner et al., 2001; Nkosi et al., 2009) who reported reduced pH in inoculated maize silage compared with the control. The $\mathrm{pH}$ of the inoculated WCSS was below 4.0 as of $\mathrm{d} 3$ of ensiling while that of the control took $7 \mathrm{~d}$ to get below 4.0 (Figure 1). However, our present study is in contrast with the work of Xing et al. (2009), who reported a lack of effect on $\mathrm{pH}$ with bacterial inoculation to sweet sorghum straw at ensiling. According to these researchers, this could be attributed to the sufficient amount of WSC contained in sweet sorghum straws, which can easily produce a rapid drop in silage $\mathrm{pH}$ without the use of additives.

Water-soluble carbohydrates are regarded as essential substrates for the growth of LAB for proper fermentation (McDonald et al., 1991). Sweet sorghum stalks have been reported to contain $250-350 \mathrm{~g}$ $\mathrm{WSC} / \mathrm{kg}$ DM (Griffiths et al., 2004). The WSC content in our WCSS prior to ensiling was $251 \mathrm{~g} \mathrm{WSC} / \mathrm{kg}$ $\mathrm{DM}$, more than sufficient for LAB (McDonald et al., 2002). However, after $25 \mathrm{~d}$ of ensiling, the LB+E treatment had higher $(P<0.05)$ residual WSC compared with the other treatments, consistent with other workers (Stokes, 1992; Masuko et al., 1996). This reflects that the WSC was not fermented completely by the LB+E treatment (Schmidt et al., 1997) and this treatment degraded NDF to WSC. The LP treated silage had lower residual WSC among the treatments, suggesting a more intensive use of sugars for LA production, consistent to Pedroso et al. (2008) when sugarcane silage was inoculated with LP.

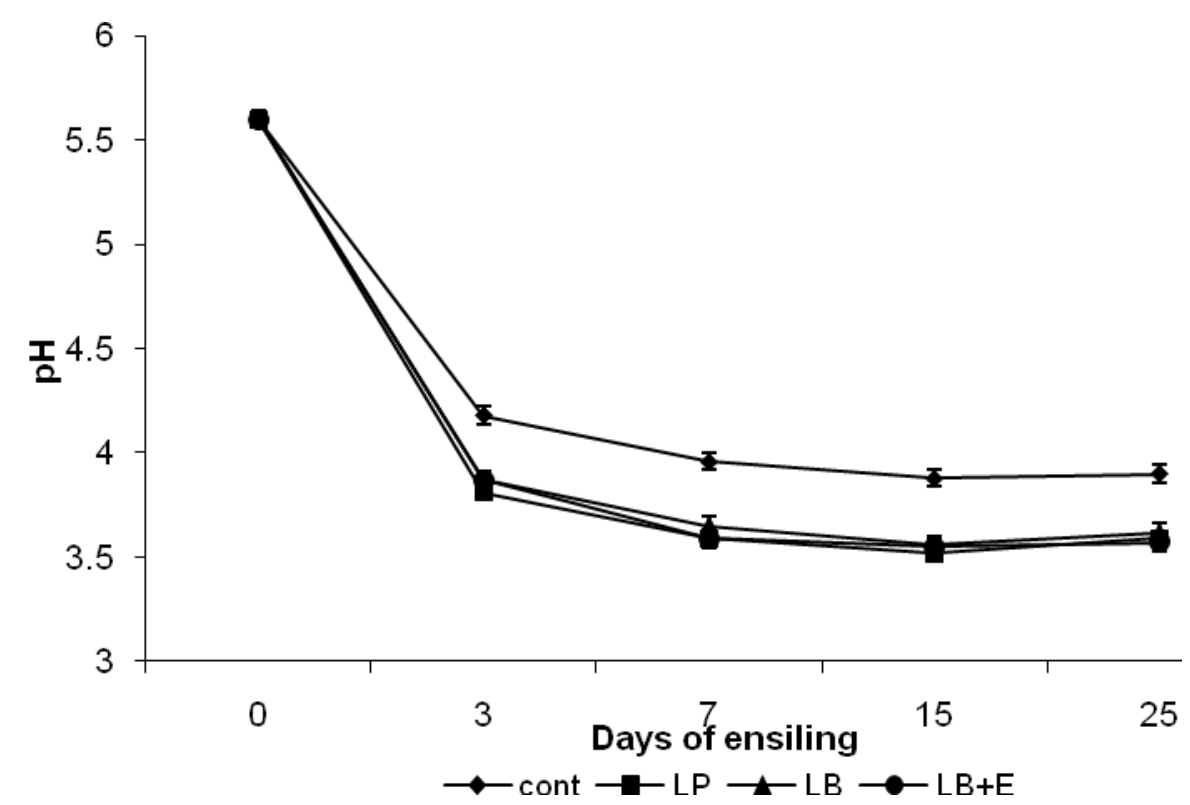

Figure 1 Effects of bacterial inoculation on the $\mathrm{pH}$ of whole-crop sweet sorghum during 25 days of ensiling.

A high-quality silage is likely to be achieved when LA is the predominant acid produced, and good quality silage should contain LA concentration in the range of 40 to $120 \mathrm{~g} / \mathrm{kg}$ DM (McDonald et al., 1991). The LA content in silage of our study was within this recommended range, an indication of well-fermented silage. However, the LA concentration recorded in our study was lower than $160 \mathrm{~g} \mathrm{LA} / \mathrm{kg} \mathrm{DM}$ reported in sweet sorghum silage (Xing et al., 2009) but consistent with that reported by Podkowka \& Podkowka (2011). It has been reported that homofermentative $\mathrm{LAB}$ or $\mathrm{LAB}+$ enzyme inoculation has positive effects on the silage fermentation by increasing LA compared with the control (Kung et al., 1991, Chen et al., 1994). As expected, inoculation increased $(P<0.05)$ the concentration of LA compared with the control. 
Table 2 Effects of bacterial inoculation and enzyme on the nutrient composition, fermentation characteristics and aerobic stability of whole-crop sweet sorghum after 25 days of ensiling $(n=3)$

\begin{tabular}{|c|c|c|c|c|c|c|}
\hline & \multicolumn{4}{|c|}{ Treatments } & \multirow{2}{*}{ SEM } & \multirow{2}{*}{$P$} \\
\hline & Control & LP & LB & $\mathrm{LB}+\mathrm{E}$ & & \\
\hline \multicolumn{7}{|c|}{ Nutrient composition (g/kg DM unless stated otherwise) } \\
\hline Dry matter & 308 & 314 & 305 & 310 & 8.17 & 0.144 \\
\hline Ash & $43.4^{\mathrm{b}}$ & $42.2^{\mathrm{b}}$ & $46.2^{\mathrm{a}}$ & $43.9^{\mathrm{b}}$ & 0.65 & 0.014 \\
\hline Crude protein & $39^{\mathrm{c}}$ & $41.8^{\mathrm{a}}$ & $41.4^{\mathrm{a}}$ & $40^{\mathrm{b}}$ & 0.28 & 0.001 \\
\hline GE (MJ/kg DM) & $18.7^{\mathrm{d}}$ & $19.2^{\mathrm{a}}$ & $18.9^{\mathrm{c}}$ & $19.0^{\mathrm{b}}$ & 0.02 & 0.001 \\
\hline Ether extract & $16.3^{\mathrm{a}}$ & $15.1^{\mathrm{b}}$ & $15.0^{\mathrm{b}}$ & $14.2^{\mathrm{c}}$ & 0.18 & 0.001 \\
\hline aNDF & $489^{\mathrm{a}}$ & $438^{\mathrm{c}}$ & $471^{\mathrm{b}}$ & $441^{c}$ & 3.37 & 0.001 \\
\hline $\mathrm{ADF}$ & $331^{\mathrm{a}}$ & $297^{\mathrm{c}}$ & $314^{\mathrm{b}}$ & $295^{\mathrm{c}}$ & 3.01 & 0.001 \\
\hline \multicolumn{7}{|c|}{ Fermentation characteristics ( $\mathrm{g} / \mathrm{kg}$ DM unless stated otherwise) } \\
\hline $\mathrm{pH}$ & $3.90^{\mathrm{a}}$ & $3.59^{\mathrm{bc}}$ & $3.62^{\mathrm{b}}$ & $3.57^{\mathrm{c}}$ & 0.004 & 0.001 \\
\hline WSC & $116.4^{\mathrm{c}}$ & $101.8^{\mathrm{d}}$ & $152.4^{\mathrm{b}}$ & $193.5^{\mathrm{a}}$ & 13.8 & 0.001 \\
\hline LA & $81.2^{\mathrm{c}}$ & $127.3^{\mathrm{a}}$ & $95.3^{\mathrm{b}}$ & $94.7^{\mathrm{b}}$ & 6.82 & 0.012 \\
\hline $\mathrm{AA}$ & $25.2^{\mathrm{c}}$ & $7.4^{\mathrm{d}}$ & $41.4^{\mathrm{a}}$ & $32.6^{\mathrm{b}}$ & 3.42 & 0.001 \\
\hline PA & 0.019 & 0.021 & 0.018 & 0.019 & 0.071 & 0.0154 \\
\hline BA & $0.121^{\mathrm{a}}$ & $0.062^{\mathrm{b}}$ & $0.069^{\mathrm{b}}$ & $0.067^{\mathrm{b}}$ & 0.084 & 0.015 \\
\hline $\mathrm{NH}_{3}-\mathrm{N}(\mathrm{g} / \mathrm{kg} \mathrm{TN})$ & $52.2^{\mathrm{a}}$ & $41.4^{\mathrm{b}}$ & $400.1^{\mathrm{b}}$ & $39.3^{b}$ & 2.62 & 0.001 \\
\hline \multirow{3}{*}{$\begin{array}{l}\text { Aerobic stability } \\
\text { No. of hours } \\
\text { pH after aerobic } \\
\text { stability test }\end{array}$} & & & & & & \\
\hline & $53^{\mathrm{b}}$ & $46^{\mathrm{c}}$ & $72^{\mathrm{a}}$ & $55^{\mathrm{b}}$ & 2.82 & 0.001 \\
\hline & $4.92^{\mathrm{b}}$ & $5.4^{\mathrm{a}}$ & $4.23^{c}$ & $4.05^{\mathrm{d}}$ & 0.019 & 0.001 \\
\hline
\end{tabular}

$\overline{\mathrm{a}-\mathrm{d}}$ Means with different superscripts in a row differ significantly $(P<0.05)$.

GE - gross energy; aNDF - amylase treated neutral detergent fibre; ADF - acid detergent fibre; WSC - water-soluble carbohydrate; LA - lactic acid; AA - acetic acid; PA - propionic acid; BA - butyric acid; $\mathrm{NH}_{3}-\mathrm{N}$ - ammonia nitrogen.

Some studies have reported a reduced concentration of LA while increasing acetic acid (AA) concentrations with LB inoculation to maize silage compared with the control (Muck, 2010). However, the AA concentrations in silages in our study were generally low compared with the LA concentration (Table 2), indicative of good preservation quality of the silage (McDonald et al., 1991). This agrees with Mari et al. (2009) who reported increased LA and AA in corn silage inoculated with LB compared with the control.

The inoculation of $\mathrm{LB}$ and $\mathrm{LB}+\mathrm{E}$ resulted in an increased $(P<0.05)$ concentration of AA compared with the other treatments. Kung et al. (2007) reported increased AA in high moisture maize that was treated with LB+E, and LB treatment was also reported to increase AA in other studies (Pedroso et al., 2008; Nkosi et al., 2009), consistent with the present study. However, the AA concentration of the LB+E treatment in our present study is higher than $20 \mathrm{~g} \mathrm{AA} / \mathrm{kg} \mathrm{DM}$, reported from sweet sorghum silage that was inoculated with a combination of inoculant and enzyme (Xing et al., 2009). This might be attributed to the fact that the latter study combined an enzyme with a homofermentative $\mathrm{LAB}$, while our present study combined an enzyme with $\mathrm{LB}$, a heterofermentative $\mathrm{LAB}$, known to increase AA.

Ammonia-N in silage reflects the degree of protein degradation, and extensive proteolysis adversely affects the utilization of $\mathrm{N}$ by ruminants (Wilkinson, 2005). Well-preserved silages should contain less than $100 \mathrm{~g}$ ammonia-N/kg TN (McDonald et al., 2002) but this can be high in forages that are high in CP content such as legumes. Our sweet sorghum silage had ammonia-N concentrations that were lower than this value, which is indicative of well-preserved silage. It has been reported that inoculation reduced proteolysis during ensiling and resulted in improved efficiency of silage protein utilization and reduced $\mathrm{N}$ losses (McDonald et al., 2002). According to McDonald et al. (1991), this effect arose as a result of $\mathrm{pH}$ reduction with 
inoculation, which inhibits protein degradation in silages. This supports our findings, since inoculation reduced $(P<0.05)$ both the $\mathrm{pH}$ and ammonia-N production compared with the control.

Silage from cereal crops is fed usually to high-producing animals as a source of energy. It is well established that inoculation of $\mathrm{LAB}$ to forage at ensiling reduces the concentration of butyric acid (BA) in silage (McDonald et al., 1991). A higher $(P<0.05)$ concentration of BA occurred in the control, leading to a reduced energy content of the silage compared with the other silages. A concentration of $<0.1 \mathrm{~g} \mathrm{BA} / \mathrm{kg} \mathrm{DM}$ is typically found in well-preserved silage (Kung \& Shaver, 2001) and our WCSS had values lower than this threshold, an indication of a well-preserved silage. In addition, BA is associated with a clostridial type of fermentation and usually associated with high-moisture silages (McDonald et al, 1991) and the WCSS had $323 \mathrm{~g} \mathrm{DM}$ at pre-ensiling. The GE recorded in the WCSS in our study is in agreement with that of Lema et al. (2000), who recorded $20.09 \mathrm{MJ} / \mathrm{kg}$ in sweet sorghum silage. Margan et al. (1994) and Tine et al. (2001) reported $18 \mathrm{GE} \mathrm{MJ} / \mathrm{kg}$ DM in maize silage, which is comparable with that of WCSS in our study.

The content of CP in our WCSS is lower than those reported in sweet sorghum silage (Morris \& McCormick, 1994, Di Marco et al., 2009, Xing et al., 2009), which ranged between 77 and 95 g CP/kg DM. This difference could be attributed to different hybrids, soil conditions and harvest stage between the two studies (Lema et al., 2000). However, Lema et al. (2000) reported $<46 \mathrm{~g} \mathrm{CP} / \mathrm{kg}$ in silage produced from various sweet sorghums, which is consistent with our present study. This CP content is too low to support animal production and may need protein supplementation to improve animal performance.

It has been reported that the effects of LAB inoculants on fibre degradation are not consistent because LAB cannot effectively use fibre as an energy source to produce lactic acid (Muck, 2010). Faber et al. (1989) attributed the lack of response with $\mathrm{LAB}$ inoculation to a lower environmental temperature that inhibited hemicellulose degradation. The LB+E and LP reduced $(P<0.05)$ the fibre content of silage compared with the other treatments, consistent with other studies (Nadeau et al., 2000). In contrast, some reports showed that LAB+enzyme inoculants (Meeske et al., 1993; Kung et al., 2007) and LAB (Faber et al., 1989) did not affect cell wall contents in silages.

The effect of acetic acid on the control of yeasts to improve silage aerobic stability was proposed by Weinberg et al. (1993). According to these researchers, increasing AA concentrations in silage inhibited spoilage micro-organisms and promoted aerobic stability. According to previous research (Taylor et al., 2002, Pedroso et al., 2008, Nkosi et al., 2009) inoculation with LB typically results in acetic acid concentrations ranging from 36 to $50 \mathrm{~g} / \mathrm{kg} \mathrm{DM}$, suitable for controlling yeast during aerobic exposure of silage. The acetic acid concentration of $40 \mathrm{~g} / \mathrm{kg}$ DM in the LB and LB+E treated WCSS was enough to control yeast. In contrast, Xing et al. (2009) reported no effects on the aerobic stability of sweet sorghum silage when either LAB or enzyme was used. This can be attributed to the fact that they used a homofermentative LAB inoculant, which is well known to reduce aerobic stability of silage (Nkosi et al., 2010). When exposed to air for five days, the LB silage had a higher aerobic stability as indicated by the higher $(P<0.05)$ numbers of hours it remained stable together with its lower $\mathrm{pH}$ value (Table 2$)$ compared with the other treatments. According to the evidence that silages of higher LA concentrations or those with more residual sugar contents are less stable when exposed to air (Weinberg et al. 1993), the aerobic stability of WCSS in our study was reduced $(P<0.05)$ with LP inoculation compared with other treatments, supporting other studies (e.g. Nkosi et al., 2010). This is also evident from Table 2 where a higher increase in $\mathrm{pH}$ was observed with LP inoculation after $5 \mathrm{~d}$ of aerobic exposure. The aerobic stability of WCSS that was treated with LB+E lasted for $55 \mathrm{~h}$, similar to the control and better than the LP treated silage. Inoculation of LB to sugarcane at ensiling resulted in a $78 \mathrm{~h}$ aerobic stability (Pedroso et al., 2008), which is comparable with the $72 \mathrm{~h}$ aerobic stability obtained in the LB treated WCSS in our study.

\section{Conclusions}

It was concluded that the WCSS produced in the present study was of good quality in terms of the fermentation characteristics. The application of LAB inoculant treatments LP, LB and LB+E resulted in reduced $\mathrm{pH}, \mathrm{BA}$ and ammonia- $\mathrm{N}$ and increased LA content in sweet sorghum silage compared with the control. The WSC content of sweet sorghum prior to ensiling was high and WSC did not limit preservation in any of the treatments. The aerobic stability of silage was reduced with the homofermentative LP treatment compared with the control. The most noticeable effect of $\mathrm{LB}+\mathrm{E}$ treatment was the reduction of fibre but increased residual WSC. The aerobic stability of LB+E silage was lower than LB treated silage. Using enzymes to increase the WSC content of crops that already have high levels of WSC may result in reduced 
aerobic stability of silage. Further work to evaluate these effects on silage produced on farm scale and on animal production performance is needed.

\section{Acknowledgements}

The authors wish to thank the Norman E. Borlaug International Agricultural Science and Technology Fellowship Programme of the USDA for funding the study, and the BIVAP of the Grain Science and Industry, KSU, Manhattan, for permission to use its facilities during the study.

\section{References}

Adewakun, L.O., Famuyiwa, A.O., Felix, A. \& Omole, T.A., 1989. Growth performance, feed intake and nutrient digestibility by beef calves fed sweet sorghum silage, corn silage and fescue hay. J. Anim. Sci. 67, 1341-1349.

AOAC, 1990. Official Methods of Analysis. $15^{\text {th }}$ ed. Association of Official Analytical Chemists, Washington, D.C., USA.

Aydin, G., Grant, R.J. \& O`Rear, J., 1999. Brown midrib sorghum in diets for lactating dairy cows. J. Dairy Sci. 82, 2127-2135.

Barker, S.B. \& Summerson, W.H., 1941. The colorimetric determination of lactic acid in biological material. J. Biol. Chem. 138, 535-54.

Billa, E., Koullas, D.P., Monties, B. \& Koukios, E.G., 1997. Structure and composition of sweet sorghum stalk components. Indust. Crops Prod. 6, 297-302.

Bryan, W.L., 1990. Solid-state fermentation of sugars in sweet sorghum. Enzyme Microbiol. Technol. 12, 437-442.

Chen, J., Stokes, R.M. \& Wallace, C.R., 1994. Effects of enzyme-inoculant systems on preservation and nutritive value of hay crop and corn silages. J. Dairy Sci. 77, 501-512.

Di Marco, O.N., Ressia, M.A., Arias, S., Aello, M.S. \& Arzadun, M., 2009. Digestibility of forage silages from grain, sweet and bmr sorghum types: comparison of in vivo, in situ and in vitro data. Anim. Feed Sci. Technol. 153, 161-168.

Dubois, M., Giles, K.A., Hamilton, J.K., Rebes, P.A. \& Smith, F., 1956. Colorimetric method for determination of sugars and related substances. Anal. Chem. 28, 350-356.

Felix, A. \& Funso, A.O., 1994. Digestibility and nitrogen balance in lambs fed grain sorghum silage, sweet sorghum silage or fescue hay. Small Rumin. Res. 14, 33-38.

Fellner, V., Phillip, L.E., Sebastian, S. \& Idziak, E.E., 2001. Effects of a bacterial inoculant and propionic acid on preservation of high moisture ear corn, and on rumen fermentation, digestion and growth performance of beef cattle. Can. J. Anim. Sci. 81, 273-280.

Genstat For Windows ${ }^{\circledR}$ 2005. The guide to Genstat Release 8. Ed. Payne, R.W., VSN International Ltd., Oxford, UK.

Griffiths, N.W., Mickan, F.J. \& Kaiser, A.G., 2004. Chapter 5: Crops and by-products for silage. Topfodder Successful silage. (2nd ed.) Eds Kaiser, A.G., Piltz, J.W., Burns, H.M. \& Griffiths, N.W. pp. 110-136.

Keady, T.W.J. \& Steen, W.J., 1994. Effects of treating low dry matter grass with a bacterial inoculant on the intake and performance of beef cattle and studies on its mode of action. Grass Forage Sci. 49, 438-446.

Kung Jr., L. \& Shaver, R., 2001. Interpretation and use of silage fermentation analysis reports. University of Wisconsin, Madison, WI, USA. Focus on Forage 3(13), 1-5.

Kung Jr., L., Tung, R.S., Maciorowski, K.G., Buffum, K., Knutsen, K. \& Aimutis, W.R., 1991. Effects of plant cell-wall degrading enzymes and lactic acid bacteria on silage fermentation and composition. J. Dairy Sci. 74, 4284-4296.

Kung Jr. L., Schmidt, R.J., Ebling, T.E. \& Hu, W., 2007. The effect of Lactobacillus buchneri 40788 on the fermentation and aerobic stability of ground and whole high moisture corn. J. Dairy Sci. 90, 2309-2314.

Lema, M., Felix, A., Salako, S. \& Bishnoi, U., 2000. Nutrient content and in vitro dry matter digestibility from various grain sorghum and sweet sorghum cultivars. J. Sust. Agric. 17, 55-70.

Lu, J., Rao, S., Le, T., Mora, S. \& Banerjees, S., 2011. Increasing cake solids of cellulosic sludge through enzyme-assisted dewatering. Process Biochem. 46, 353-357. 
Margan, D.E., Moran, J.B. \& Spence, F.B., 1994. Energy and protein value of combinations of maize silage and red clover hay for ruminants, using adult sheep as a model. Aust. J. Exp. Agric. 34, 319-329.

Masuko, T., Kodama, I. \& Ohta, N., 1996. Effects of addition of formic acid or mixture of bacterial inoculant and enzyme on fermentation of orchardgrass (Dactylis glomerata), Timothy (Phleum pratense L.) and alfalfa (Medicago sativa) silages. Grassl. Sci. 42, 13-19.

McDonald, P., Henderson, A.R. \& Heron, S.J.E., 1991. The Biochemistry of Silage. Chalcombe Publications, Marlow, Buckinghamshire, UK.

McDonald, P, Edwards, R.A., Greenhalgh, J.F.D. \& Morgan, C.A., 2002. Animal Nutrition. $6^{\text {th }}$ ed. Longman Scientific and Technical. Prentice Hall, New Jersey, USA.

Meeske, R., Ashbell, G., Weinberg, Z.G. \& Kipnis, T., 1993. Ensiling forage sorghum at two stages of maturity with the addition of lactic acid bacterial inoculants. Anim. Feed Sci. Technol. 43, 165-175.

Morris, D.R. \& McCormick, M.E., 1994. Ensiling properties of sweet sorghum. Commun. Soil Sci. Plant Anal. 25 (15-16), 2583-2595.

Muck, R.E., 2010. Silage additives and management issues. Proceedings of Idaho Alfalfa Forage Conference, Best Western Burley Inn, Burley, Idaho, USA. 16-17 February, pp. 49-55.

Muck, R.E. \& Kung Jr. L., 2007. Chapter 40: Silage production. In: Forages, Vol. II. The Science of Grassland Agriculture. (6th ed.) Eds Barnes, R.F., Nelson, C.J., Moore, K.J. \& Collins, M., Iowa State Press, Ames, I.A. pp. 617-633.

Nadeau, E.M.G., Buxton, D.R., Russell, J.R., Allison, M.J. \& Young, J.W., 2000. Enzyme, bacterial inoculant, and formic acid effects on silage composition of orchardgrass and alfalfa. J. Dairy Sci. 83, 1487-1502.

Nkosi, B.D., Meeske, R., Palic, D., Langa, T., Leeuw, K-J. \& Groenewald, I.B., 2009. Effects of ensiling whole crop maize with bacterial inoculants on the fermentation, aerobic stability, and growth performance of lambs. Anim. Feed Sci. Technol.154, 193-203.

Nkosi, B.D, Meeske, R., Van der Merwe, H.J. \& Groenewald, I.B., 2010. Effects of homofermentative and heterofermentative bacterial silage inoculants on potato hash silage fermentation and digestibility in rams. Anim. Feed Sci. Technol. 157, 195-200.

Oude Elferink, S.J.W.H., Krooneman, J., Gottschal, J.C., Spoestra, S.F., Faber, F. \& Driehuis, F., 2001. Anaerobic conversion of lactic acid to acetic acid and 1,2-propanediol by Lactobacillus buchneri. Appl. Environ. Microbiol. 67, 125-132.

Pedroso, A.F., Nussio, L.G., Loures, D.R.S., Paziani, S.F., Ribeiro, J.L., Mari, L.J., Zopollatto, M., Schmidt, P., Mattos, W.R.S. \& Horii, J., 2008. Fermentation, losses and aerobic stability of sugarcane silages treated with chemical or bacterial additives. Sci. Agric. 65, 589-594.

Podkowka, Z. \& Podkowka, L., 2011. Chemical composition and quality of sweet sorghum and maize silages. J. Cent. Europ. Agric. 12, 294-303.

Pryce, J.D., 1969. Modification of the Barker \& Summerson method for the determination of lactic acid. Analyst 94, 1151-1152.

Putman, D.H., Leueschen, W.E., Kanne, B.K. \& Hovrestad, T.R., 1991. A comparison of sweet sorghum cultivars and maize for ethanol production. J. Prod. Agric. 4, 377-381.

Schmidt, J., Sipocz, J., Kaszas, I., Szakacs, G., Gyepes, A. \& Tengerdy, R.P., 1997. Preservation of sugar content in ensiled sweet sorghum. Biores. Technol. 60, 9-13.

Selmer-Olsen, I., Henderson, A.R., Robertson, S. \& McGinn, R., 1993. Cell wall degrading enzymes for silage. 1. The fermentation of enzyme-treated ryegrass in laboratory silos. Grass Forage Sci. 48, 55-63.

Sheperd, A.C. \& Kung Jr., L., 1996. Effects of an enzyme additive on composition of corn silage ensiled at various stages of maturity. J. Dairy Sci. 79, 1767-1773.

Snedecor, G.W. \& Cochran, W.G., 1980. Statistical Methods. (7th ed.), Iowa State University Press. Ames, Iowa, USA.

Spoelstra, S.F., Van Wikselaar, P.G. \& Harder, B., 1992. The effects of ensiling whole crop maize with a multi-enzyme preparation on the chemical composition of the resultant silages. J. Sci. Food Agric. 60, 223-228.

Stokes, M.R., 1992. Effects of an enzyme mixture, an inoculant and their interaction on silage fermentation and dairy production. J. Dairy Sci. 75, 764-773.

Suzuki, M. \& Lund, C.W., 1980. Improved gas liquid chromatography for simultaneous determination of volatile fatty acids and lactic acid in silage. J. Agric. Food Chem. 28, 1040-1041. 
Taylor, C.C.N., Ranjit, J., Mills, J.A., Neylon, J.M. \& Kung Jr., L., 2002. The effect of treating whole plant barley with Lactobacillus buchneri 40788 on silage fermentation, aerobic stability and nutritive value for dairy cows. J. Dairy Sci.85, 1793-1800.

Tine, M.A., McLeod, K.R., Erdman, R.A. \& Baldwin, V.I., 2001. Effects of brown midrib corn silage on the energy balance of dairy cattle. J. Dairy Sci. 84, 885-895.

Van Soest, P.J., Robertson, J.B. \& Lewis, B.A., 1991. Methods of dietary fiber, neutral detergent fiber, and non-starch polysaccharides in relation to animal nutrition. J. Dairy Sci. 74, 3583-3597.

Weinberg, Z.G., Ashbell, G, Hen, Y. \& Azriel, A., 1993. The effect of applying lactic acid bacteria on the aerobic stability of silages. J. Appl. Bacteriol. 75, 512-518.

Weissbach, F.E. \& Strubelt, C., 2008. Correcting the dry matter content of maize silages as a substrate for biogas production. 63 Landtechnik 2, 82-83.

Wilkins, J.R., Hutchinson, K.J., Wilson, R.F. \& Harris, C.E., 1971. The voluntary intake of silage by sheep. 1. Interrelationships between silage composition and intake. J. Agric. Sci., Camb. 77, 531-537.

Wilkinson, J.M., 2005. In: Silage. Part 6: Assessing Silage Quality. Chapter 19: Analysis and clinical assessment of silage. Ed. Wilkinson, J.M., Chalcombe Publications, UK. pp. 198-208.

Xing, L., Chen, L.J. \& Han, L.J., 2009. The effect of an inoculant and enzymes on fermentation and nutritive value of sorghum straw silages. Bioresour. Technol. 100, 488-491. 